\title{
Problematika Dalam Pembelajaran Berbasis Virtual Learning Environment (VLE) Terhadap Siswa dan Guru SMA/MA Pada Materi Biologi Di Masa COVID-19
}

\author{
Tomi Apra Santosa ${ }^{1}$, Lufri $^{2}$, Zulyusri $^{3}$ \\ 1, 2,3 Program Studi Pendidikan Biologi, FMIPA, Universitas Negeri Padang, \\ Jl. Prof. Dr. Hamka Air Tawar,Padang Indonesia \\ Email penulis pertama: santosatomiapra@gmail.com
}

\begin{abstract}
The research aims to find out the problem of Learning based on Virtual Learning Environment (VLE) for high school / MA students in biological materials in the COVID-19 era. This research is qualitative research with a fenomenology approach. Data collection techniques in research are observations, interviews, and questionnaires. The technique of ensuring the validity of data is triangulation. Data analysis techniques are data reduction, data presentation, and data verification. The results of the study can be concluded that SMA Negeri 12 Kerinci students have difficulty in understanding the concepts and learning materials and teachers has difficulty in practicing and evaluating learning outcomes, SMA Negeri 4 Kerinci students lack motivation and participation in learning and teachers have difficulty in making teaching materials, and MAS Koto Rendah students often experience internet network disruptions, students are less active in learning, and students have low motivation to learn virtually and teachers have difficulty in making teaching materials and explaining materials.
\end{abstract}

Keywords: Learning, Virtual Learning Environment (VLE), Biology, Pandemic COVID-19.

\begin{abstract}
Abstrak
Penelitian bertujuan untuk mengetahui problematika pembelajaran berbasis Vrtual Learning Environment (VLE) terhadap siswa SMA/MA pada materi biologi di masa COVID-19. Penelitian ini adalah penelitian kualitatif dengan pendekatan fenomenologi. Teknik pengumpulan data dalam penelitian adalah observasi, wawancara, dan angket. Teknik menjamin keabsahan data adalah triangulasi. Teknik analisis data adalah reduksi data, penyajian data, dan verifikasi data. Hasil penelitian dapat disimpulkan bahwa SMA Negeri 12 Kerinci $40 \%$ siswa mengalami kesulitan dalam memahami materi biologi dan $40 \%$ guru kesulitan melaksanakan praktiku, SMA Negeri 4 Kerinci $44 \%$ siswa kurang senang dengan materi biologi hal disebabkan kabanyak tugas yang diberikan guru dan $80 \%$ guru kesulitan dalam membuat bahan ajar berbasis virtual, MAS Koto Rendah $60 \%$ siswa mengalami gangguan jaringa internet dalam belajar dan $65 \%$ guru kesulitan dalam membuat bahan ajar.
\end{abstract}

Kata Kunci: Pembelajaran, Virtual Learning Environment (VLE), Biologi, Pandemi COVID-19

Copyright (c) 2021 Tomi Apra Santosa, Lufri, Zulyusri

$\triangle$ Corresponding author: Tomi Apra Santosa

Email Address: santosatomiapra@gmail.com

Received 01 Januari 2021, Accepted 01 Januari 2021, Published 02 Januari 2021

\section{PENDAHULUAN}

Pandemi COVID-19 merupakan musibah terbesar yang dialami dunia termasuk Indonesia sejak maret 2020 (Delgado et al., 2020; Argaheni, 2020; Anawaty, 2020). Wabah pandemi COVID19 telah mengubah berbagai sektor ekonomi, politik, sosial, dan pendidikan. (Maity et al., 2020;Kusumaningrum, 2020). Coronavirus Diseases 2019 ( COVID-19) adalah penyakit baru yang belum teridentifikasi yang dapat menyerang bagian pernapasan pada manusia serta gejala yang ditimbulkan bervariasi melalui orang ke orang (Dewi, 2020; Karakaya et al., 2020; Kanematsu, 2020). Gejala klinis yang ditimbulkan oleh COVID-19 adalah demam tinggi diatas 38 derajat celcius, batuk, dan sulit bernapas (Sulata \& Hakim, 2020). Apabila gejala tersebut ditemukan pada seseorang, 
maka orang tersebut sudah terpapar virus COVID-19. Virus ini telah membuat perubahan besar pada sistem pembelajaran.

Pembelajaran di masa pandemi ini dilakukan secara daring atau online. Pembelajaran daring adalah sistem pembelajaran dengan memanfaatkan jaringan internet untuk melakukan hubungan pembelajaran (Sadikin et al., 2020). Hal ini didasarkan Surat Edaran Kemendikbud Nomor 2 Tahun 2020 dan Nomor 3 Tahun 2020 tentang pembelajaran daring dan berkerja dari rumah dengan tujuan memutuskan penyebaran COVID-19 (Sutriyani, 2020). Penggunaan teknologi memiliki peranan yang sangat besar dalam melakukan pembelajaran di masa pademi ini. Penggunaan berbagai macam flatform pembelajaran, seperti zoom meeting, google meeting, google classroom, edmodo dan whatshapp merupakan manfaat adanya teknologi. Maka pembelajaran daring sangat membutuhkan kreativitas dan kemampuan siswa dalam memanfaatkan teknologi (Mansyur, 2020; Yuangga \&Sunarsi, 2020).

Pembelajaran Virtual Learning Environment (VLE) adalah suatu sistem pembelajaran dengan menggunakan flatform pembelajaran. Pembelajaran ini harus ditembuh oleh jutaan sekolah siswa dan guru seluruh Indonesia. Siswa dan guru harus bisa melaksanakan kegiatan tersebut secara efektif. Sebanyak 28, 6 Juta Sekolah Dasar dan Sederajat, 13,1 Juta Sekolah Menengah Pertama dan Sederajat, 11, 3 Juta Sekolah Menengah Atas dan Sederajat serta 6,3 Juta Pendidikan Tinggi melakasanakan pemebelajaran virtual dari rumah (Kemendikbud, 2020). Pembelajaran sistem ini memiliki banyak kelemahan yang harus segera diatasi pemerintah ( Hamdani, 2020).

Siswa dan guru merupakan orang yang merasakan dampak yang cukup besar di bidang pendidikan. Siswa dan guru bisa meningkat kualitas pendidikan melalui Pembelajaran Jarak Jauh (PJJ) (Park et al., 2020). Pembelajaran Jarak Jauh (PJJ) juga dirasakan oleh siswa dan guru SMA/MA. Hal ini menyebakan siswa dan guru SMA/MA menghadapi tantangan dalam pembelajaran. Pembelajaran adalah sistem yang harus dilakukan secara sistematik (Muldayanti, 2013). Dengan demikian, siswa dan guru SMA/MA harus meningkatkan kreativitas dan ketrampilan dalam menggunakan aplikasi pembelajaran.

Biologi adalah ilmu yang mempelajari tentang makhluk hidup di kehidupan kita (Shen et al., 2018). Biologi merupakan mata pelajaran yang harus dikuasai oleh siswa. Akan tetapi, siswa harus mampu menerap dan memahami materi yang diterangkan oleh guru. Guru merupakan orang yang memberikan pengetahuan, kompetensi, dan nilai-nilai kepada siswa (Kinh et al., 2016). Siswa dan guru masa pandemi ini harus mampu melaksanakan kegiatan belajar biologi berbasis virtual.

Penelitian In Setyorini (2020) menunjukan bahwa siswa, guru, dan orang tua mengalami problematika dalam kegiatan belajar mengajar seperti kurangnya penguasaan teknologi, biaya internet yang mahal, dan adanya jam tambahan orang tua untuk mendampingi anak belajar. Penelitian oleh Reni Wijaya, dkk (2020) menunjukan bahwa mahasiswa dan dosen mengalami kendala dalam menggunakan e-learning, seperti sinyal yang lemah, server yang sering error, kurangnya komunikasi antara dosen dan siswa, penguasaan penggunaan e-learning masih rendah dan rendahnya penguasaan 
materi untuk matakuliah praktek. Penelitian Alfiah, dkk (2020) menunjukan bahwa pembelajaran di rumah mengalami masalah dalam penggunaan teknologi dan terkendalanya koneksi internet dalam proses belajar mengajar. Penelitian ini bertujuan untuk mengetahui problematika dalam pembelajaran berbasis Virtual Learning Environment (VLE) terdahap siswa dan guru SMA/MA pada materi biologi di era COVID-19.

\section{METODE}

Penelitian ini adalah penelitian kualitatif dengan pendekatan fenomenologi. Fenomenologi adalah strategi penelitian di mana di dalamnya peneliti mengidentifikasi hakikat pengalaman manusia tentang suatu fenomena tertentu (Creswell, 2009). Teknik pengumpulan data menggunakan observasi, wawancara, dan angket. Subjek penelitian adalah siswa dan guru SMA Negeri 12 Kerinci berjumlah 10 orang siswa dan 5 orang guru, siswa dan guru SMA Negeri 4 Kerinci berjumlah 8 orang siswa dan 4 orang guru, dan siswa dan guru MAS Koto Rendah berjumlah 5 orang siswa dan 2 orang guru. Teknik analisis data adalah triangulasi. Triangulasi adalah data atau informasi dari satu pihak diperiksa kebenarannya dengan cara memperoleh informasi dari sumber lain (Afifuddin, 2012). Teknik analisis data adalah analisis data interaktif, yaitu reduksi data (data collection), penyajian data (data display), dan kesimpulan atau verifikasi (conslution drawing/verification) (Prastowo, 2016).

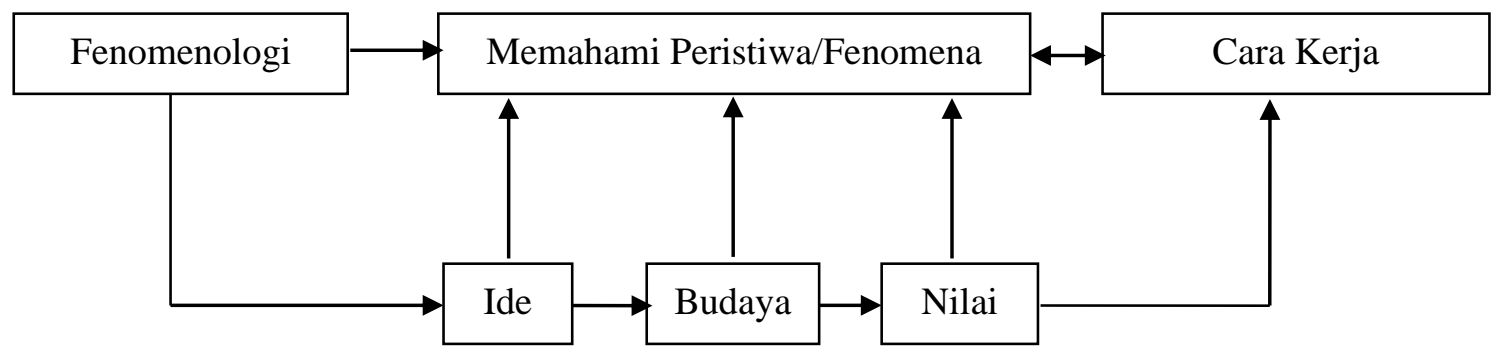

Bagan.1 Alur penelitian Fenomenologi

\section{HASIL DAN DISKUSI}

Pembelajaran merupakan suatu proses belajar dan mengajar antara siswa dan guru serta segala fasilitas yang mendukung (Jayawardana et al., 2020). Pembelajaran biologi siswa dan guru SMA/MA mengalami berbagai problematika. Hal tersebut merupakan dampak dari wabah pandemi COVID-19. Semua sistem pembelajaran tidak dilaksanakan di sekolah melainkan di rumah ( Ayuni,et.al., 2020). Sistem pembelajaran di masa pandemi COVID-19 dilaksana secara virtual learning environment atau daring. Model pembelajaran berbasis virtual atau online alternatif pembelajaran pada saat pandemi ini (Cahyani et al., 2020). berbagai macam media virtual learning environment yang dipakai oleh siswa SMA/MA 


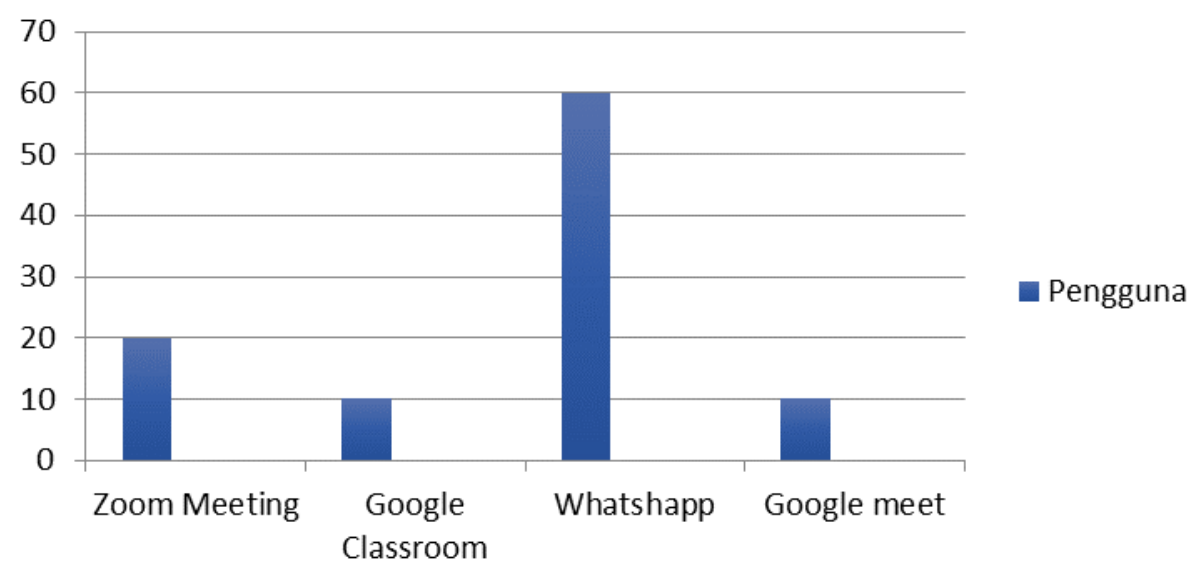

Diagram.1 Media Virtual Yang Digunakan SMA Negeri 12 Kerinci

Berdasarkan diagram di atas sebanyak $60 \%$ siswa dan guru SMA Negeri 12 Kerinci menggunakan aplikasi whatshapp dalam melaksanakan pembelajaran daring, $20 \%$ siswa dan guru SMA Negeri 12 Kerinci menggunakan zoom meeting, dan $10 \%$ siswa dan guru SMA Negeri 12 Kerinci menggunakan google classroom dan google meet. Kemudahan dalam menggunakan aplikasi whatsapp menjadi faktor utama siswa dan guru. Aplikasi whatsapp memiliki dampak yang positif terhadap pencapaian siswa saat mengekuti ujian (Supriyatin, 2020). Akan tetapi, dalam proses belajar mengajar siswa mengalami problemtika atau masalah .

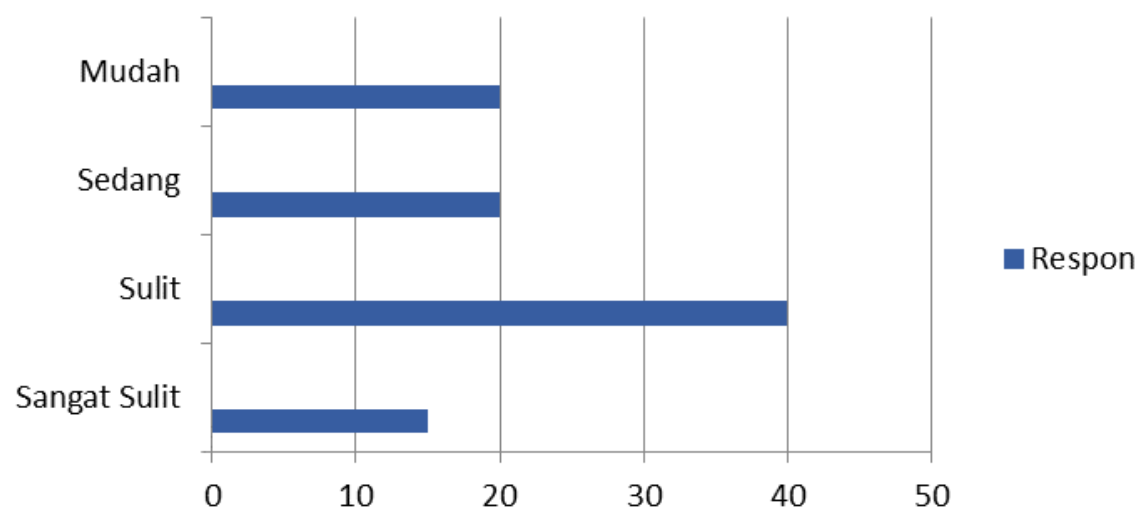

Diagram.2 Pemahaman siswa Terhdap Materi Biologi

Bedasarkan diagram di atas $40 \%$ siswa menyatakan sulit, $20 \%$ siswa menyatakan sedang, $20 \%$ siswa menyatakan mudah, dan $10 \%$ siswa menyatakan siswa memahami materi biologi yang diberikan oleh guru. Pembelajaran daring masih dianggap sulit oleh sebagian sekolah (Ayuni, et.al 2020 ;Utami et al., 2020). Siswa memiliki kemampuan yang berbeda dalam memahami materi pelajaran biologi. Siswa dituntut harus mampu menguasai teknologi untuk pembelajaran (Benner \& Mistry, 2020). 


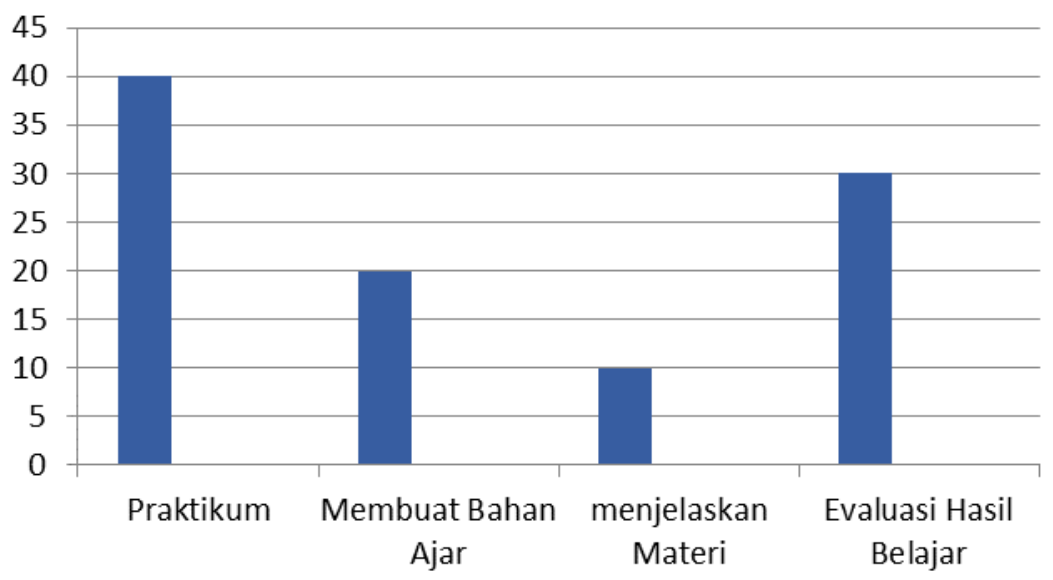

Diagram.3 Problematika Guru SMA Negeri 12 Kerinci

Berdasarkan diagram di atas guru SMA Negeri 12 Kerinci mengalami problematika di mana $40 \%$ guru menyatakan praktikum, $30 \%$ menyatakan evaluasi hasil belajar siswa, $20 \%$ membuat bahan ajar, dan $10 \%$ menyatakan menjelaskan materi pelajaran. Problematika berupa praktikum merupakan kelemahan dari pembelajaran berbasis virtual atau daring. Jika diperhatikan materi biologi merupakan materi yang banyak menggunakan praktikum.

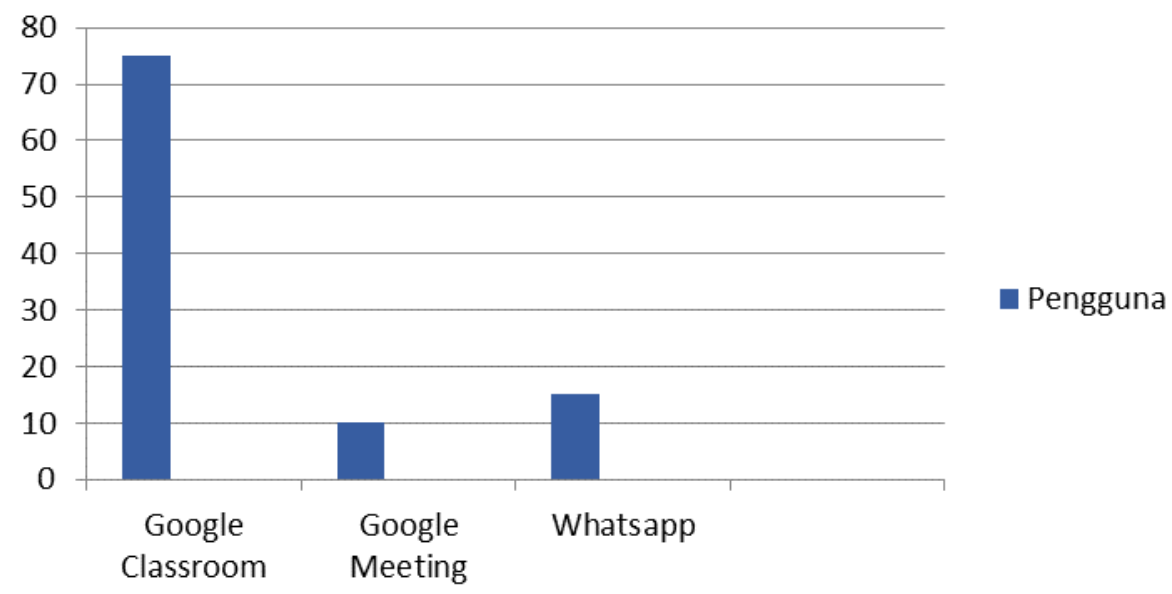

Diagram.4 Media Virtual Yang Digunakan SMA Negeri 4 Kerinci

Berdasarkan diagram di atas siswa dan guru SMA Negeri 4 Kerinci $75 \%$ menggunakan google classroom, $15 \%$ menggunakan google meeting, dan $10 \%$ menggunakan whatsapp. Penggunaan aplikasi google classroom sangat efektif digunakan oleh siswa dan guru SMA Negeri 4 Kerinci. Google classroom mampu membuat salinan tugas siswa secara cepat dan otomatis (Astini, 2020). Selain itu google classroom memiliki tingkat kefektifan, kemudahan, dan kualitas layanan yang lebih 
baik (Rosali, 2020). Akan tetapi, penggunaan pembelajaran menggunakan google classroom memberikan problematika bagi siswa dan guru SMA Negeri 4 Kerinci.

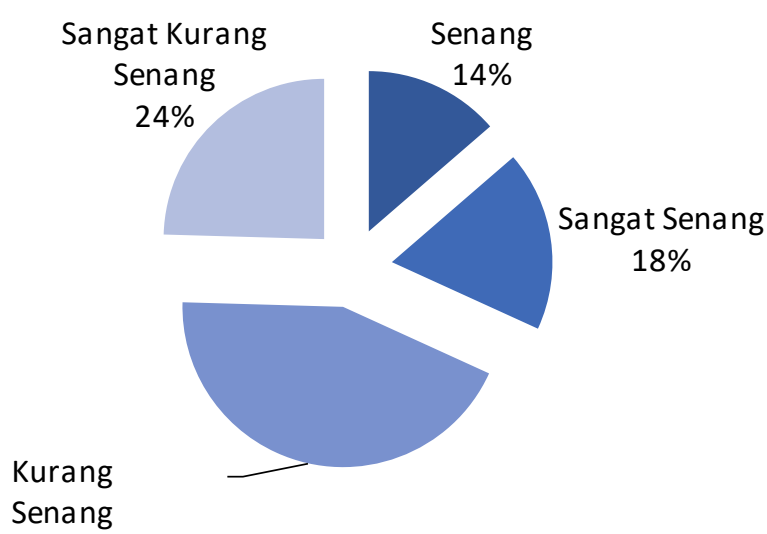

Diagram.5 Tingkat Kesenangan Siswa dalam Belajar virtual

Berdasarkan diagram diatas $44 \%$ siswa SMA Negeri 4 Kerinci kurang senang dengan pembelajaran berbasis virtual. Hal ini terjadi karena banyak tugas yang diberikan guru kepada siswa daripada guru menjelaskan materi pelajaran biologi. Seharusnya guru yang mampu menyesuaikan antara tugas dan materi pelajara biologi yang disampaikan kepada siswa. Dengan begitu siswa senang, aktif, dan termotivasi dalam mengikut kegiatan belajar mengajar.

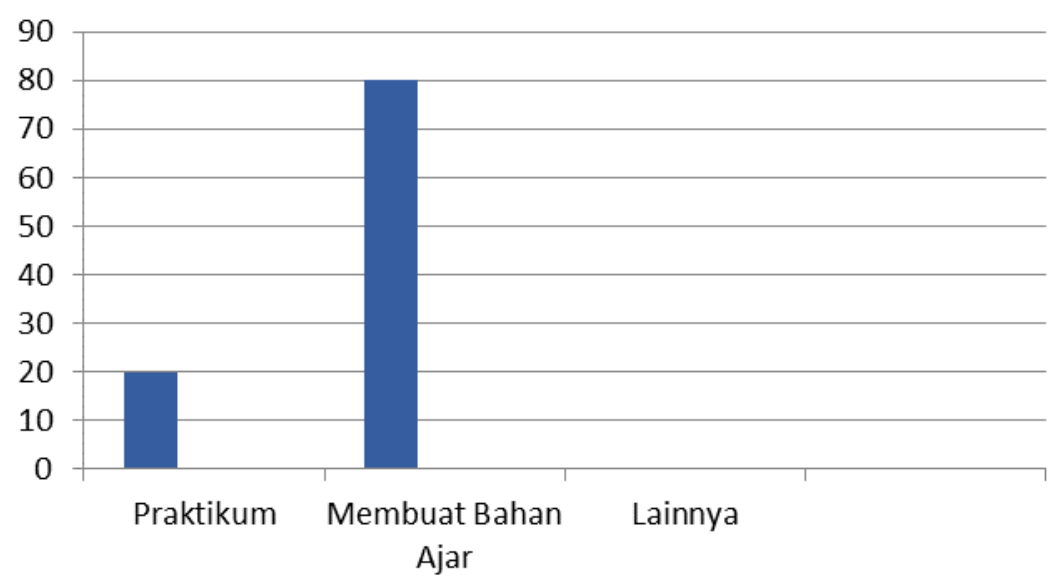

Diagram.6 Problematika Guru SMA Negeri 4 Kerinci

Berdasarkan diagram di atas bahwa guru SMA Negeri 4 Kerinci mengalami masalah atau problematika dimana $80 \%$ guru SMA Negeri 4 Kerinci kesulitan dalam membuat bahan ajar dengan sistem pembelajaran virtual atau daring. Pembelajaran daring memanfaatkan jaringan internet dalam penyampaian materi belajar (Rigianti, 2020). Kesulitan ini membuat guru harus mencari solusi agar 
dapat membuat bahan ajar berbasis elektronik. Dan juga guru harus bisa menggunakan media teknologi dalam mengatasi masalah ini (Chiou, 2018).

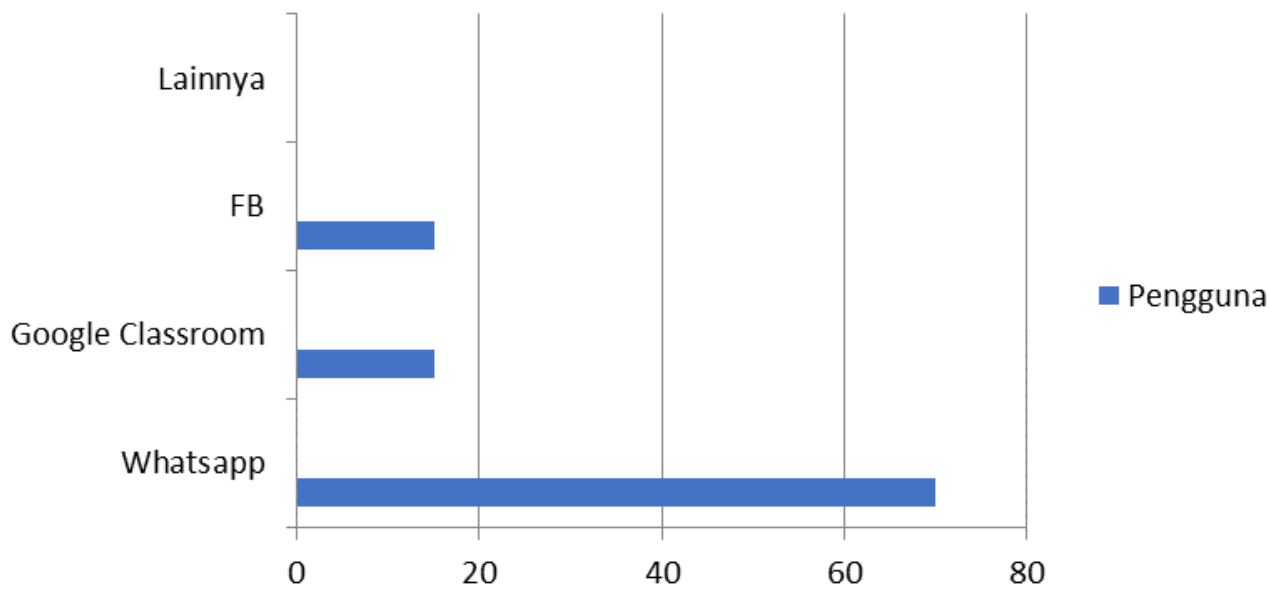

Diagram. 7 Media Virtual MAS Yang Digunakan Koto Rendah

Siswa dan guru MAS Koto Rendah menggunakan beberapa aplikasi yang dapat mendukung pembelajaran berbasis virtual atau daring saat ini. Berdasarkan diagram di atas $70 \%$ siswa dan guru MAS Koto Rendah menggunakan aplikasi Whatsapp untuk melaksanakan proses belajar mengajar di masa pandemi ini. Penggunaan whatsapp mampu mengerim pesan dalam bentuk teks, suara dan video serta banyak digunakan.(Astini, 2020; Kuntarto, 2017).

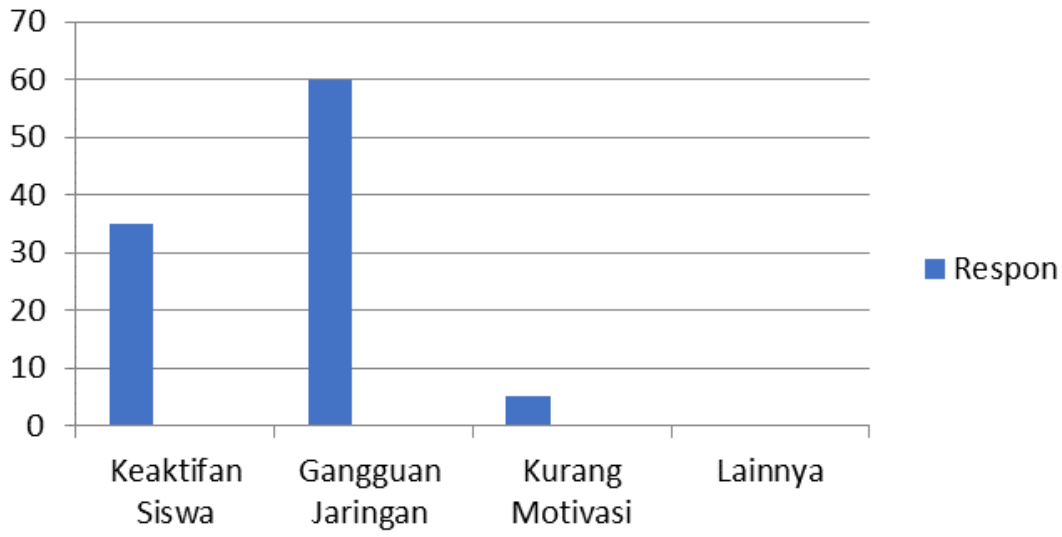

Diagram.8 Problemtika Siswa MAS Koto Rendah

Siswa MAS Koto Rendah mengalami problematika belajar materi biologi $60 \%$ siswa mengalami gangguan jaringan. Umumnya siswa MAS Koto Rendah umumnya tinggal di daerah pendesaan. Selain itu, problematikan juga di alami berupa kurang aktif dalam belajar, dan kurang termotivasi dalam belajar materi biologi. Karena tidak semua siswa mampu dalam mengikuti pembelajaran 
berbasis virtual atau daring ini. Keaktifan siswa dalam kegiatan belajar mengajar dapat dilihat ketika siswa mampu mengerjakan tugas, memecahkan masalah, dan mampu mempresentasi hasil belajar (Nurhayati, 2020). Dan motivasi dapat dilihat ketika siswa bersemangat dalam mengikuti kegiatan belajar mengajar di dalam kelas.

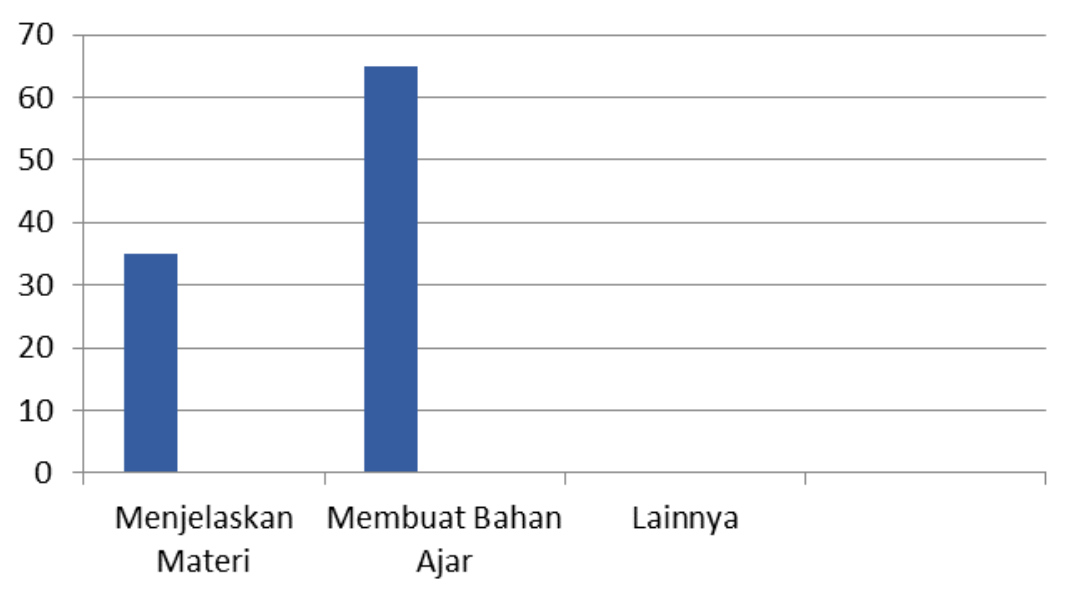

Diagram.9 Problematika Guru MAS Koto Rendah

Guru MAS Koto Rendah mengalami problematika $65 \%$ berupa kendala dalam membuat bahan ajar dan $35 \%$ mengalami dalam menjelaskan materi biologi. Permasalahan tersebut umumnya di alami oleh guru dalam melaksanakan pembelajaran virtual atau daring. Guru muda lebih mahir dalam menggunakan media pembelajaran virtual atau daring untuk menjelaskan bahan ajar dan materi pembelajaran biologi (Atsani, 2020). Pembelajaran juga kurang optimal ketika guru menjelaskan materi pelajaran kepada siswa yang berupa materi biologi dalam bentuk hafalan (Anggianita \& Rizal, 2020). Dengan demikian, guru senior harus meningkatkan kompetensi dalam penggunaan media pembelajaran daring yang telah ada.

\section{KESIMPULAN}

Dari penjelasan di atas dapat disimpulkan bahwa SMA Negeri 12 Kerinci SMA Negeri 12 Kerinci $40 \%$ siswa mengalami kesulitan dalam memahami materi biologi dan $40 \%$ guru kesulitan melaksanakan praktiku, SMA Negeri 4 Kerinci $44 \%$ siswa kurang senang dengan materi biologi hal disebabkan kabanyak tugas yang diberikan guru dan $80 \%$ guru kesulitan dalam membuat bahan ajar berbasis virtual, MAS Koto Rendah $60 \%$ siswa mengalami gangguan jaringa internet dalam belajar dan $65 \%$ guru kesulitan dalam membuat bahan ajar. 
Problematika Dalam Pembelajaran Berbasis Virtual Learning Environment (VLE) Terhadap Siswa dan Guru SMA/MA

\section{UCAPAN TERIMA KASIH}

Peneliti mengucapkan terima kasih kepada siswa dan guru SMA Negeri 12 Kerinci, SMA Negeri 4 Kerinci, dan MAS Koto Rendah yang telah membantu peneliti baik berupa materil maupun nonmateril dalam menyelesaikan penelitian ini.

\section{REFERENSI}

Acep Roni Hamdani1, A. P. (2020). Efektifitas Implementasi Pembelajaran Daring (Full Online) Dimasa Pandemi Covid- 19 Pada Jenjang Sekolah Dasar Di Kabupaten Subang. Didaktik: Jurnal Ilmiah PGSD STKIP Subang, 6(1), 1-9.

Afifuddin, B. A. S. (2012). Metode Penelitian Kualitatif. Jakarta: Pustaka Setia.

Anggianita, S., \& Rizal, M. S. (2020). Persepsi Guru terhadap Pembelajaran Daring di Sekolah Dasar Negeri 013 Kumantan. Journal of Education Research, 1(2), 177-182.

Argaheni, N. B. (2020). SISTEMATIK REVIEW : DAMPAK PERKULIAHAN DARING SAAT PANDEMI COVID-19 TERHADAP MAHASISWA INDONESIA A Systematic Review : The Impact of Online Lectures during the COVID-19 Pandemic Against Indonesian Students. PLACENTUM Jurnal Ilmiah Kesehatan Dan Aplikasinya, 8(2).

Astini, N. K. S. (2020). Pemanfaatan Teknologi Informasi dalam Pembelajaran Tingkat Sekolah Dasar pada Masa Pandemi Covid-19. JURNAL LAMPUHYANG, 11(2), 13-25.

Atsani, L. G. M. Z. (2020). TRANSFORMASI MEDIA PEMBELAJARAN PADA MASA PANDEMI COVID-19. Al-Hikmah: Jurnal Studi Islam, 1(1), 82-93.

Benner, A. D., \& Mistry, R. S. (2020). Child Development During the COVID-19 Pandemic Through a Life Course Theory Lens. CHILD DEVELOPMENT PERSPECTIVES, O(0), 1-8. https://doi.org/10.1111/cdep.12387

Cahyani, A., Listiana, I. D., Puteri, S., Larasati, D., Islam, U., Sunan, N., Yogyakarta, K., Islam, U., Sunan, N., Yogyakarta, K., Islam, U., Sunan, N., Yogyakarta, K., \& Belajar, M. (2020). Motivasi Belajar Siswa SMA pada Pembelajaran Daring di Masa Pandemi Covid-19. IQ (Ilmu Al-Qur'an): Jurnal Pendidikan Islam, 3(01), 123-140.

Chiou, H. (2018). The impact of situated learning activities on technology university students ' learning outcome. Ministry of Science \& Technology, 7(5), 1-13. https://doi.org/10.1108/ET04-2018-0092

Creswell, J. W. (2009). Research: Design: Pendekatan Kualitatif, Kuantitatif, dan Mixed. Pustaka Pelajar. 
Despa Ayuni1?, Tria Marini2, Mohammad Fauziddin 3, Y. P. (2021). Jurnal Obsesi : Jurnal Pendidikan Anak Usia Dini Kesiapan Guru TK Menghadapi Pembelajaran Daring Masa Abstrak. Jurnal Obsesi: Jurnal Pendidikan Anak Usia Dini, 5(1), 414-421. https://doi.org/10.31004/obsesi.v5i1.579

Jayawardana, H. B. A., Sugiarti, R., \& Gita, D. W. I. (2020). Inovasi Pembelajaran Biologi di Era Revolusi Industri 4 . 0 (Issue September, pp. 58-66).

KANEMATSU, D. M. B. A. H. (2020). TEACHING DURING THE COVID-19 PANDEMIC BY (pp. $1-6)$.

Kemendikbud. (2020). Dampak COVID-19 Bagi Pendidikan. Jakarta: Kemendikbud.

Kinh, T., Jane, K., Tracey, S., Gannon, J., Kieu, T. K., Singer, J., \& Gannon, T. J. (2016). Education for sustainable development in Vietnam : lessons learned from teacher education. International Journal of Sustainability in Higher Education, 17(6), 1467-6370. https://doi.org/10.1108/IJSHE-05-2015-0098

Kusumaningrum, E. (2020). The Effect of Distance Learning in an Online Learning Framework on Student Learning Independence during the Covid-19 Pandemic. In International Conference on Education and Technology (ICET (pp. 182-185).

Mansyur, A. R. (2020). Dampak COVID-19 Terhadap Dinamika Pembelajaran Di Indonesia. Education and Learning Journal, 1(2), 113-123.

Muldayanti, N. D. (2013). Jurnal Pendidikan IPA Indonesia. Jurnal Pendidikan IPA Indonesia, 2(1), $12-17$.

Nurhayati, E. (2020). Meningkatkan Keaktifan Siswa Dalam Pembelajaran Daring Melalui Media Game Edukasi Quiziz pada Masa Pencegahan Penyebaran Covid-19. Jurnal Penelitian Dan Pengembangan Pendidikan, 7(3), 145-150.

Park, J. J., Park, M., Jackson, K., \& Vanhoy, G. (2020). Brief Peer Reviewed Essay Multidisciplinary Perspectives in Higher Education Engineering Education Under COVID-19 Pandemic Environment. OJED International Journal of Multidisciplinary Perspectives in Higher Education, 5(1), 160-166.

Prastowo, A. (2016). Metode Penelitian Kualitatif : Dalam Perspektif Rancangan Penelitian. Ar-Ruzz Media.

Rigianti, H. A. (2020). KENDALA PEMBELAJARAN DARING GURU SEKOLAH DASAR DI KABUPATEN BANJARNEGARA. Elementary School, 7(2), 297-302. 
Rosali. (2020). AKTIFITAS PEMBELAJARAN DARING PADA MASA PANDEMI COVID -19 DI. Geography Science Education Journal (GEOSEE), 1(1), 21-30.

Sadikin, A., Hamidah, A., Pinang, K., Jl, M., Ma, J., Km, B., Indah, M., Jaluko, K., Kode, K. M., \& Indonesia, P. (2020). Pembelajaran Daring di Tengah Wabah Covid-19 ( Online Learning in the Middle of the Covid-19 Pandemic ). BIODIK: Jurnal Ilmiah Pendidikan Biologi, 6(1), 214224.

Shen, K., Li, T., \& Lee, M. (2018). Learning biology as ' Increase ones ' knowledge and understanding ': studying Taiwanese high school students' learning strategies in relation to their epistemic views and conceptions of learning in biology. International Journal of Science Education, 6(93), 1-22. https://doi.org/10.1080/09500693.2018.1522013

Sulata, M. Ardi, A. A. H. (2020). GAMBARAN PERKULIAHAN DARING MAHASISWA ILMU KEOLAHRAGAAN UNESA DI MASA PANDEMI COVID-1. Jurnal Kesehatan Olahraga, $8(3), 147-156$.

Supriyatin, T. (2020). Analisis Pembelajaran Filsafat MIPA Berbasis Daring pada Mahasiswa Pendidikan Biologi di Era Pandemi Covid-19 yang digunakan oleh guru . Titin Supriyatin, 1(1), $18-21$.

Sutriyani, W. (2020). STUDI PENGARUH DARING LEARNING TERHADAP MINAT DAN HASIL BELAJAR MATEMATIKA MAHASISWA PGSD ERA PANDEMI COVID-19 Wulan Sutriyani Program Studi PGSD FTIK UNISNU Jepara Pendahuluan Pembelajaran merupakan suatu proses yang dilakukan dengan memberikan pendidika. Jurnal Pendidikan Dasar : Jurnal Tunas Nusantara, 2(1), 155-165. 